$1-1-1962$

\title{
Acorn consumption by white-footed mice (Peromyscus leucopus)
}

Robert Leo Smith

Follow this and additional works at: https://researchrepository.wvu.edu/ wv_agricultural_and_forestry_experiment_station_bulletins

\section{Digital Commons Citation}

Smith, Robert Leo, "Acorn consumption by white-footed mice (Peromyscus leucopus)" (1962). West Virginia Agricultural and Forestry Experiment Station Bulletins. 482T.

https://researchrepository.wvu.edu/wv_agricultural_and_forestry_experiment_station_bulletins/652 @ WVU. It has been accepted for inclusion in West Virginia Agricultural and Forestry Experiment Station Bulletins by an authorized administrator of The Research Repository @ WVU. For more information, please contact ian.harmon@mail.wvu.edu. 




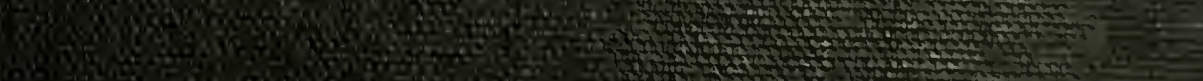

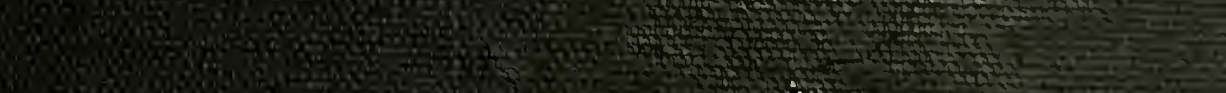
6.

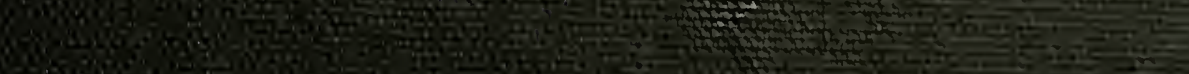

Sold

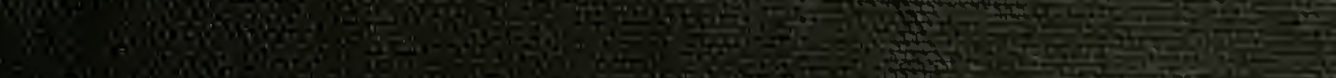

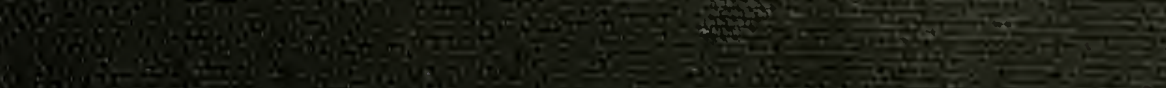
130 6.

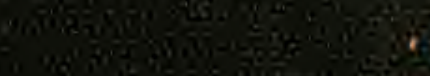



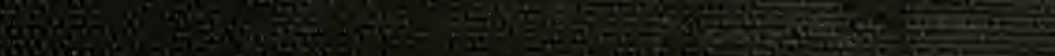

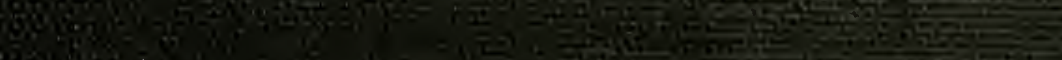

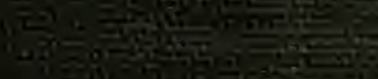

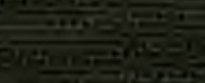

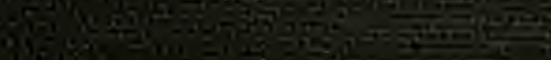

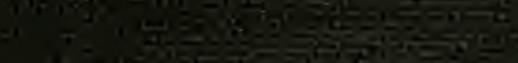

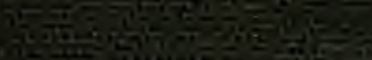
4.

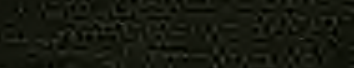
Exiy

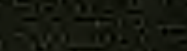

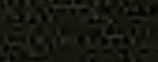
$5 \times 2$ wesis Py

Lech

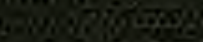

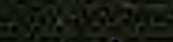


$9=28$ ia


ge 60 -

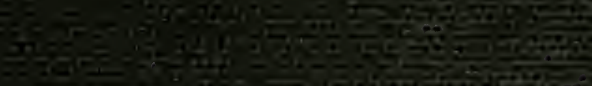


3.

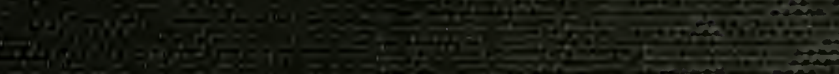
tor

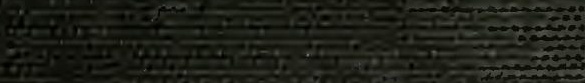
cho H 4. 4 \%







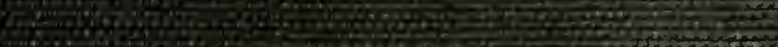

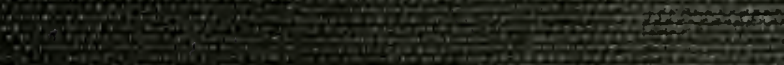


Digitized by the Internet Archive in 2010 with funding from

Lyrasis Members and Sloan Foundation 


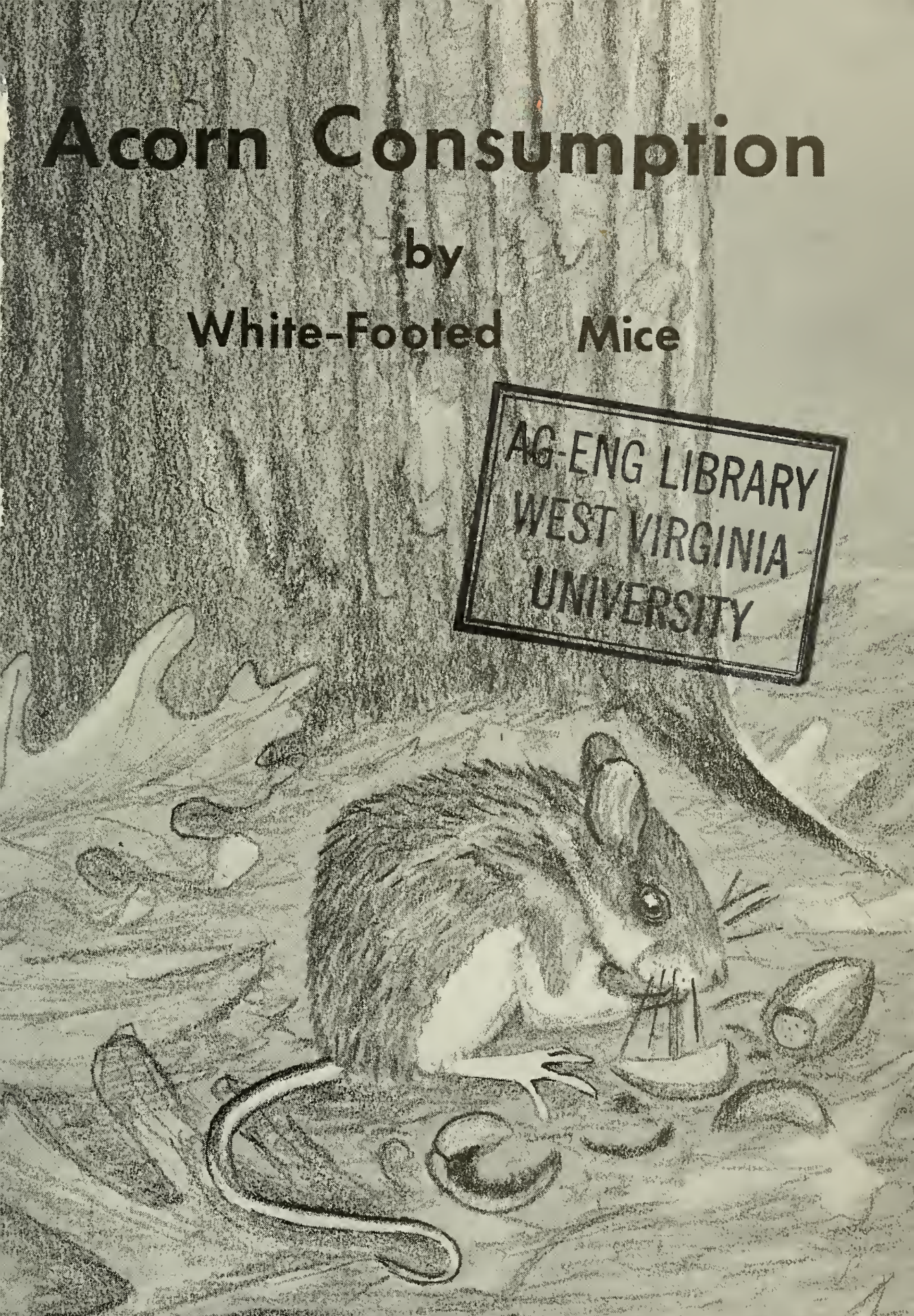

Builletin 482T 


\section{THE AUTHOR}

The author of Acorn Consumption by WhiteFooted Mice (Peromyscus leucopus) is Robert Leo Smith, Assistant Wildlife Biologist in the West Virginia University Agricultural Experiment Station and Assistant Professor of Wildlife Management, Division of Forestry, College of Agriculture, Forestry and Home Economics, West Virginia University. He also drew the cover illustration.

West Virginia UNIVERSITY

Agrigultural Experiment Station

College of Agriculture, Forestry, and Hone Economics

A. H. Vanlandingham, Director

MORGANTOWN 


\section{Acorn Consumption By White-Footed Mice (Peromyscus leucopus)}

Robert Leo Smith

Fin. OR nearly 50 years foresters have regarded white-footed and deer mice (Peromyscus spp.) as notorious forest tree seed eaters. Many believe that these rodents influence the success of forest reproduction, especially with the conifers (Willis, 1914; Smith and Aldous, 1947; Shaw, 1954; Spencer, 1954; Abbott, 1961). Silviculturists interested in the regeneration of hardwood stands, especially oaks throughout the Appalachians, have called attention to the influence of animals on oak reproduction (Korstian, 1927; Downs and McQuilken, 1944; Krajicek, 1955; Christisen and Korschgen, 1955; Tryon and Carvell, 1958, 1962).

The only published study of acorn consumption involving the white-footed mouse (Peromyscus leucopus) is by Verme (1957). Four mice and five chipmunks (Tamias striatus) were observed in this study, but neither the weight of the acorns fed nor the daily weights of the animals were recorded. Verme found that the mice consumed, over a 61-day period, an average of 1.8 acorns per animal per day. The chipmunks ate 6.1 acorns per day.

The most intensive quantitative study of forest tree seed consumption by mice was done by Turcek (1956) in Czechoslovakia. His study involved Apodemus flavicollis, a European woodland mouse very similar in appearance, size, habits and ecology to Peromyscus leucopus. In several experiments involving different seeds, the mice consumed from 1.28 to 3.49 grams dry matter per day, or from 0.042 to $0.157 \mathrm{gm}$. of dry matter of food per gram of body weight. Dry matter consumption, per day, varied from 4.3 to 16 per cent of the body weight of the mice. On the average they assimilated 84 per cent of all food consumed, but only 5 per cent was used for increasing body weight.

Disagreement exists concerning the preference by mammals and birds for one acorn species over another. Downs and McQuilken (1940) and Christisen and Korschgen (1955) believe that birds and mammals show no preference for any particular species of acorn. The latter, however, did note that utilization of acorns on the ground varied from 4 per cent for black jack oak (Quercus marildanica Muenchn) to 37.2 per cent for white oak (Quercus alba, L).

Verme (1957) found a decided preference by chipmunks and white-footed mice for white oak acorns over red oak (Quercus rubra $\mathrm{L}$ ). 
This preference was most pronounced in white-footed mice who ate only 16 per cent of all red oak acorns presented.

Baumgras (1944) writes that fox squirrels (Sciurus niger) preferred in order: white oak, black oak (Quercus velutina L), red oak, walnuts (Juglans niger L); and corn (Zea mays). Fox squirrels gained weight only on white oak; two of the three squirrels on a red oak diet died within ten days.

\section{The Study}

During the winter of 1959-60 a quantitative study was made to determine acorn consumption and preference by white-footed mice, and to determine whether or not mice consumed and assimilated more acorns of one species than another. The study consisted of two separate consumption feeding trials involving chestnut oak (Quercus prinus L.) and white oak, and a preference trial involving chestnut oak, white oak, and red oak acorns.

The acorn species involved were selected because of the availability of large quantities of mast needed for the study and because they represented the most common oaks of the region.

\section{Methods}

The white-footed mice were wild individuals live-trapped in woodlands in the vicinity of Morgantown, West Virginia.

The animals were kept in individual cages $9 \times 12 \times 71 / 2$ inches in size. The cages, including the floor, were made of $1 / 4$-inch mesh hardware cloth. Aluminum lids provided access into the cages for handling and cleaning. Each cage contained a small cardboard box shelter containing cut paper for nesting material. The cages were raised one inch above the shelf upon which they were placed for the duration of the trials. Fecal material and feeding debris were collected in paper trays beneath the cages.

Except for experimental periods, the mice were fed commercial mouse pellets, apples, chopped meat, and acorns. They had access to water, through drinking tubes, at all times.

The temperature of the room in which the mice were housed was $68^{\circ} \mathrm{F}$.

The cages and drinking tubes were scrubbed and nesting material replaced as needed.

\section{The Experiments}

EXPERIMENT 1. In the first feeding trial five mice, numbers 1, 3, 4 , 5, and 6, were fed unpeeled chestnut oak acorns for two five-day periods. Each day of the trial a quantity of acorns, usually four, more than sufficient for daily consumption, was placed in the cages. Weights 
of the daily ration of acorns for each mouse was determined to the nearest hundredth of a gram and recorded. At a standard time the following morning, the mice were removed from their cages and weighed. Weights were recorded to the nearest hundredth of a gram.

All fecal material and acorn remains beneath and inside the cages were gathered, carefully separated, and placed in marked envelopes. This material was oven dried at $90^{\circ} \mathrm{C}$ for 48 hours and then weighed. The dry weight equivalent of acorns fed was determined from a sample of 100 acorns taken from the same lot as fed, and oven dried in the same manner. The wet weights of acorns fed were then converted to a dry weight basis from the conversion factor obtained.

Between experimental periods, mice were fed commercial laboratory mouse pellets and acorns, and occasionally, raw ground beef.

EXPERIMENT 2. The techniques involved in this feeding trial were essentially the same as in Experiment 1. Ten mice, however, were involved, numbers $1,3,4,5,6,8,9,10,11$ and 12 . They were divided into two randomly selected groups. Group $A$ included 1, 5, 8, 9, 11; Group B included 3, 4, 6, 10, 12. Group A was fed chestnut acorns the first week and white oak the second, while Group B was fed white oak the first week and chestnut oak the second.

EXPERIMENT 3. The final experiment, a preference test, involved mice 1, 3, 4, 5, 6 and 7. Each day, for a five-day period, each mouse was fed, free choice, five chestnut oak, five white oak and five red oak acorns. The total of 15 represents nearly five times the amount needed for daily maintenance. The following morning all acorns and debris were removed and the treatment of each acorn recorded as nibbled, peeled, or consumed. During this trial, 450 acorns, 150 each of the three species, were fed. Neither the mice nor the acorns were weighed.

\section{The Statistical Methods}

The experiments were designed so that the data could be analyzed in several ways. Analysis of variance with the F test was used to evaluate data in Experiments 1 and 2 on consumption, assimilation between mice and days within groups, consumption and assimilation between trials and acorn species, and regression of consumption on days, weight, and assimilation. Relation between weight and consumption was determined by calculating the correlation coefficient. To eliminate variability between quantity consumed and quantity assimilated by each mouse, the percentage assimilated, obtained by clividing the amount assimilated (amount consumed - feces) by the quantity consumed, was also used to compare mice and days. The percentages were converted to angles for analysis (Snedecor, 1956). The $t$ test was used to determine significance between means for paired comparisons of consumption and assimilation between weeks in Experiment 1. Normal regression equations were determined for days, weight, and assimilation 


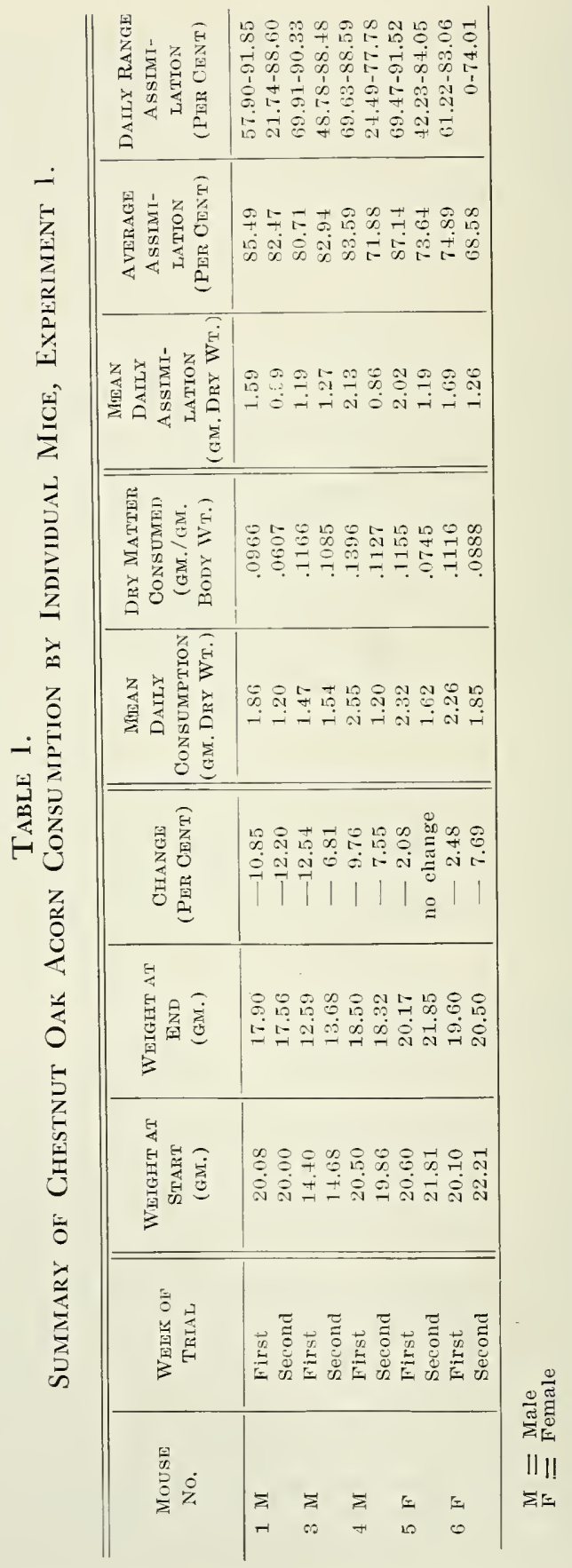


F I G URE 1. Relationship between the percentage of chestnut oak acorns assimilated and number of days on diet.

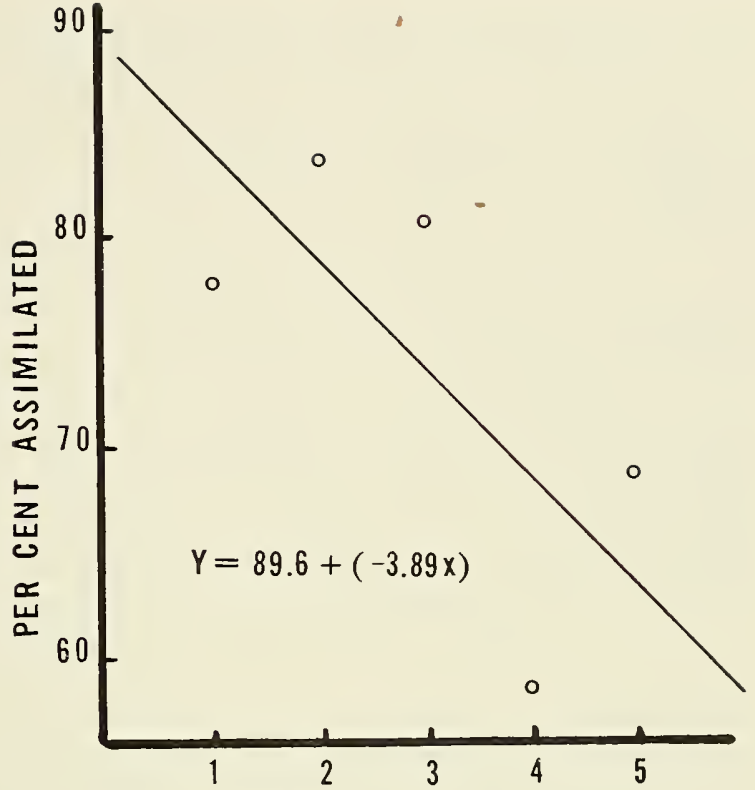

DAYS

and the forward solutions and mean square of the residuals obtained. The forward solution was then recalculated, using the Kincer and Mattice method (Kincer \& Mattice, 1928) for determining the most significant variable. Significance of preferences between acorns was determined by the Chi-square.

\section{Results}

Experiment 1. Chestnut Oak Acorn Consumption

Contrary to what one would expect, no significant difference, either in acorn consumption or in acorn assimilation, existed among mice during both the first and the second weeks. All mice assimilated approximately 80 per cent of the chestnut acorns consumed. Consumption between days, however, differed, significant at the 1 per cent level, during the first week. During the second week this difference did not exist. The daily range of assimilation by the mice varied from 0 to 91.85 per cent (Table 1 ), significant at the 5 per cent level for the first week and at the 1 per cent level for the second week.

Consumption appeared to decline daily, but a regression between average daily consumption and days was not significant. The downward trend suggested in consumption showed up when the percentage assimilated, pooled for both weeks, was plotted against days. Assimilation declined rapidly from the first to the fifth day, and was significant at the 5 per cent level (Figure 1). 
Consumption fell off sharply between the first and second weeks; the difference between the two was significant at the 5 per cent level. Average acorn consumption during the first week was $2.09 \pm 0.1992$ gm. dry wt., and during the second it was $1.48 \pm 0.1425 \mathrm{gm}$. Likewise, a significant difference existed between the percentage assimilated each week.

Thus not only did the quantity of chestnut oak acorns eaten decline from one week to the next, but the ability of the animals to assimilate the chestnut acorns also declined.

Throughout the trial the mice ate an average of $1.79 \pm 0.1288$ gm. of dry matter per mouse per day. This amounts to 10.25 per cent of their body weight in dry matter or approximately 19 per cent in fresh matter. Based on this data, white-footed mice consume daily one chestnut oak acorn weighing at least $2.57 \mathrm{gm}$. dry weight, of which 72 per cent (1.85 gm.) is edible. (The average dry weight of chestnut oak acorns used in the experiment was $2.77 \mathrm{gm}$.)

All mice lost weight during the trial. Weight losses ranged from no change to 12.54 per cent. During the 48-hour period between the trials, when the mice were fed a commercial laboratory mouse food and acorns, they regained the weight lost during the week (Table 1). This rapid weight recovery emphasizes the premise that chestnut oak acorns alone hardly constitute a maintenance diet for white-footed mice.

\section{Experiment 2. Chestnut Oak and White Oak Acorn Consumption}

Acorn consumption did not differ significantly in three of the four feeding groups in Experiment 2, two of the white oak and one of the chestnut oak. Differences in consumption, significant at the 1 per cent level, did occur between mice in Group A when they were on the chestnut oak diet. No significant difference existed in consumption between days in any of the four separate feeding groups.

Mice in Group B, however, differed in their assimilation of both chestnut and white oak acorns, significant at the 1 per cent level. Differences in assimilation, significant at the 1 per cent level, also existed between days in Group B when the mice were on the chestnut oak acorn diet. Group A, however, showed no differences in assimilation by mice and between days on either acorn diet.

Both groups of mice consumed more chestnut oak acorns than white oak acorns, significant at the 1 per cent level, and they also assimilated more, significant at the 5 per cent level. Since no significant difference existed between trials, the difference between species stands out all the more sharply. No correlation existed between the weight of the mice and the consumption of acorns. Nor did significant relationships occur among days, weight of mouse, or quantity of white oak and chestnut oak acorns consumed. The variation in assimilation exhibited by the mice in Group B reflected the indiviclual's metabolism 
rather than weight. Sealander (1952) also noted that little relationship existed between body weight changes of mice and the amount of food consumed.

The mice consumed each day $3.72 \pm 0.1732 \mathrm{gm}$. dry weight of chestnut oak acorns and $2.29 \pm 0.0953 \mathrm{gm}$. dry weight of white oak acorns. This is equivalent to 18.41 per cent of body weight on the chestnut oak acorn diet and 10.89 per cent of the white oak.

The mice assimilated 89.45 per cent of the chestnut oak acorns consumed and 85.95 per cent of the white oak. Based on these figures each mouse would require in the field at least two chestnut oak acorns weighing a minimum of $2.77 \mathrm{gm}$. dry weight and four white oak acorns (edible portion, 68 per cent) weighing at least $0.96 \mathrm{gm}$. dry weight.

The mice, as a group, lost 3.5 times more weight on the chestnut oak acorn diet than on white oak (Table 2). The mean loss on the white oak acorn diet was 1.86 per cent and on chestnut oak acorns the mean loss was 6.40 per cent. Average weight loss on white oak acorns was $0.40 \mathrm{gm}$. and on chestnut oak, $1.40 \mathrm{gm}$. per mouse.

\section{Experiment 3. Acorn Preference}

White-footed mice shorred a decicled preference for white oak acorns over chestnut oak and red oak. In fact, red oak virtually was rejected. Only 0.8 per cent of 150 red oak acorns fed to the 6 mice was consumed. The Chi-square test shows a low probability $(<0.005)$ for equal choice among the three.

Since mice destroy more than they consume, the additional damage in gnawed and peeled acorns also is of considerable interest to foresters. Here again Chi-square is highly significant, revealing a greater proportion of white oak destroyed and/or consumed. Of all white oak acorns breached, however, 77 per cent were eaten. This contrasts sharply with chestnut oak and red oak acorns, in which only 19 per cent and 5 per cent respectively of all acorns were eaten.

Each mouse was quite individualistic in the number of acorns it destroyed. Mouse 1 damaged or ate 69 per cent of all acorns, while Mouse 4 destroved only 22 per cent. On an average, the mice destroyed and/or consumed 47.55 per cent of all acorns to which they had access.

Although no quantitative data were kept on individual feeding behavior, the mice did exhibit considerable individual differences. Mouse 9, a female, was a persistent hoarder. She fed on only a fer and stored many of the remaining acorns in her nest box. On the other hand, numbers 1 and 3 were "peelers." They peeled the hulls off most of the acorns, on some days all of them, and left the kernels untouched. The mice breached the acorns at the basal end and then proceeded to peel them. As a result, the remains were thin peelings rather than empty hulls. 


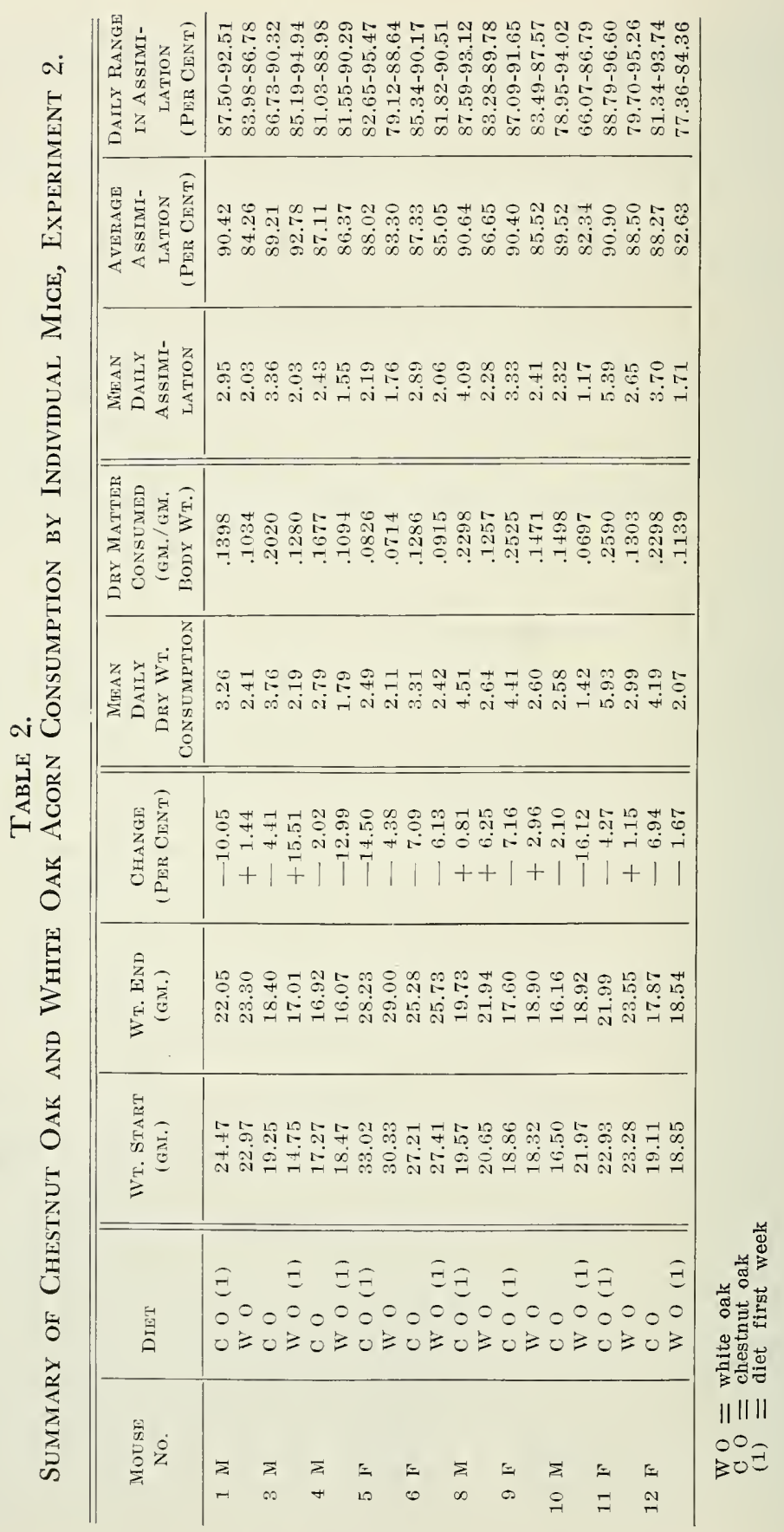




\section{Discussion and Conclusions}

Although the white-footed mice long have been regarded as seed eaters, this study indicates that acorns alone are an inadequate diet for a white-footed mouse. The rapid recovery of lost weight on a balanced diet for 48 hours contrasts sharply with weight loss over a fiveday period on an acorn diet. Even during the fall when acorns may be abundant, the mice must and do resort to other foods to meet their dietary requirements. Hamilton (1941) found that during the fall and winter the per cent of occurrence of insects in the diet of Peromyscus was 72.8 per cent compared to 43.9 per cent for the incidence of mast.

When given a free choice the mice showed a decided preference for one acorn species over another. Red oak was virtually rejected, chestnut oak was taken occasionally, and white oak was strongly preferred. The mice consumed fewer white oak acorns, assimilated a smaller percentage of them, yet maintained weight better on the white oak acorn diet than on the chestnut oak.

Nutritionally some difference dloes exist between white and chestnut oak acorns (Table 3). Both contain nearly the same quantity of available protein, nitrogen extract, and crude fiber.

White oak contains 25 per cent more fat or ether extract, which may explain why the mice could maintain body weight on a lesser quantity of white oak acorns. An important difference between the two acorns is the tannin content. Chestnut oak contains nearly twice as much tannin as white oak. Tannin, in addition to imparting a bitter taste which would explain the preference for white oak, possibly may interfere in some way with metabolism. In spite of the much richer fat content of red oak acorns, four times that of white

TABLE 3 .

Chemigal. Composition of Red OAK, Chestnut Oak, and White OAK Acorns.*

\begin{tabular}{|c|c|c|c|c|c|c|c|}
\hline \multirow{3}{*}{$\begin{array}{l}\text { Constituents } \\
\text { (Per Cent) }\end{array}$} & \multicolumn{7}{|c|}{ SPECIES OF ACORN } \\
\hline & \multicolumn{3}{|c|}{ RED OAK } & \multicolumn{2}{|c|}{ Chestnut OAK } & \multicolumn{2}{|c|}{ WHITE OAK } \\
\hline & & DRY & FRESH & DRY & FrEsh & DRY & Fresh \\
\hline  & & 2.42 & 1.50 & 2.22 & 1.11 & 2.47 & 1.39 \\
\hline Crude Fiber ............ & & 3.10 & 1.92 & 2.62 & 1.31 & 2.47 & 1.30 \\
\hline Ether Extract & & 20.81 & 12.87 & 5.05 & 2.52 & 6.32 & 3.33 \\
\hline $\mathrm{N}$-free Extract & & 67.11 & 41.45 & 83.17 & 41.52 & $\$ 2.32$ & 43.37 \\
\hline Available Protein .... & & 6.13 & 3.81 & 6.25 & 3.13 & 6.00 & 3.13 \\
\hline Lignin . & & 2.99 & 1.85 & 2.50 & 1.25 & 2.64 & 1.39 \\
\hline Cellulose .......... & & 4.14 & 2.56 & 3.53 & 1.76 & 3.24 & 1.71 \\
\hline Tannin ........... & & 9.77 & 6.04 & 10.43 & 5.20 & 5.58 & 2.94 \\
\hline $\mathrm{Ca} / \mathrm{Mg}$ & $\mathrm{T}$ & .07 & $\mathrm{~T} \quad .05$ & $\mathrm{~T} \quad .09$ & $\mathrm{~T} \quad .04$ & $\mathrm{~T} .08$ & $\mathrm{~T} \quad .05$ \\
\hline$P \quad$ & & .14 & .08 & .15 & .08 & .16 & .08 \\
\hline
\end{tabular}

*Waino, W. IV. and E. B. Forbes, "The Chemical Composition of Forest Fruits and Nuts from Pennsylvania." Journ. Agr. Rescarch, 62:627-635 (1941). 
oak, high content of tannin makes the acorn unacceptable and even deadly when consumed as the sole food source.

The quantity of food consumed compared favorably with that reported by Sealander (1952), by Chew (1948), by Dice (1922), and by Turcek (1956). The mice in this experiment consumed from 1.48 to $3.72 \mathrm{gm}$. dry weight of chestnut oak acorns and $2.29 \mathrm{gm}$. of white oak. On a fresh basis this is approximately $5.12 \mathrm{gm}$. of chestnut oak acorns and $2.62 \mathrm{gm}$. of white oak. The value for chestnut oak consumption is close to the daily consumption of six grams estimated by Hamilton (1941). The experimental mice consumed an equivalent of 23 per cent of their total body weight daily of chestnut oak acorns in contrast to Hamilton's estimated 30 per cent for mice in the wild. Daily consumption by mice under laboratory conditions would be less than in the wild, since the animals are confined and the temperature is higher and more constant. Food consumption in Peromyscus increases as the temperature decreases. Sealander (1952) found that Peromyscus consumed 30 per cent more food at $8.5^{\circ} \mathrm{C}\left(47^{\circ} \mathrm{F}\right)$ than at $20.5^{\circ} \mathrm{C}$ $\left(77^{\circ} \mathrm{F}\right)$.

Food preferences, as well as the inability of mice to maintain themselves exclusively on acorns, forces some reappraisal of the estimates of acorn consumption by mice. These estimates usually are based on an assumed mouse density, which may or may not be accurate. Mouse density fluctuates widely from year to year. In fact, an abundance and scarcity of mast itself may influence mouse abundance. Jameson (1953) found that the extension of the breeding season of deer mice in Sierra Nevada into late summer and fall and even winter depended largely on mast production by pines (Pinus spp.), oaks (Quercus spp.), Douglas fir (Pseudotsuga menziesii (Poir) Britton) and manzanita (Arctostapliylos spp.). A year of mast failure is followed by a scarcity of deer mice, because breeding then ceases in June (Jameson, 1955).

A second assumption is that acom consumption in captivity is equivalent to that under natural conditions. Obviously it is not, since the mice are forced to feed on a pure acorn diet. When offered acorn, apples, raw chopped beef, and commercial mouse pellets, the mice often ignored the acorns. The most that laboratory feeding tests can do is indicate the potential for acorn consumption if mice are forced to live on acorns alone, a highly improbable situation.

Peromyscus, as well as squirrels and chipmunks and other rodents, undoubtedly do consume quantities of acorns in the fall and early winter, since acorns are a rich source of carbohydrates and fats for energy and heat production.

More significant than consumption, perhaps, is the quantity of acorns destroyed by mice. In the laboratory, the mice damaged or consumed close to 48 per cent of all acorns with which they came in contact. Of these, more chestnut oak and red oak acorns were damaged than consumed. This figure would be higher under laboratory con- 
ditions, since the mice, for the lack of other activity, may have spent some time breaching acorns.

Turcek (1956) found that partially damaged acorns, those gnawed at the basal end, would still germinate. Under woodland conditions in the Appalachians, daniaged acorns would have to be written off, even though they potentially could germinate, because of the rapidity with which the damaged acorns would be invaded by fungi and insects of the forest floor.

Although white-footed mice do eat and damage acorns, the fact that they do not feed exclusively on acorns and that they exhibit considerable preference suggests that these small mammals have little influence on oak reproduction. If they did, then this influence should be most conspicious in white oak. Such is not the case. Tryon and Carvell (1958) found through their studies in northern West Virginia that the abundance of white oak reproduction exceeded that of red oak by more than 70 per cent, even though red oak is a more abundant seed producer. In addition, for equal numbers of red and white oak acorns, white oak seedlings were five times as numerous. Tryon and Carvell concluded that because of their smaller size, white oak acorns were covered more readily and thus protected from damage. If mice can discover acorns and coniferous seeds in artifically planted areas, any partially buried white oaks on the forest floor would not be too difficult for the mice to find. Since they virtually ignored the red oak acorns, mice would have little effect on red oak reproduction.

\section{Summary}

During the winter of 1959-60, 10 white-footed mice (Peromyscus leucopus) in several groups were fed acorns of chestnut oak (Quercus prinus L); chestnut oak and white oak (Quercus alba L); and chestnut oak, white oak and red oak (Quercus rubra $\mathrm{L}$ ) to determine quantitatively the amount of daily acorn consumption and acorn preference.

In Experiment 1, involving chestnut oak acorns alone, no significant difference existed in amount of acorns consumed among mice and for the second week of the experiment among days. During the first week, consumption from day to day differed significantly at the 1 per cent level. Likewise, no significant difference in assimilation existed among mice, but a significant difference occurred among days. Consumption and assimilation declined daily. The regression of consump. tion on days was not significant, but regression of assimilation on days was significant at the 5 per cent level.

Consumption decreased significantly between the first and second weeks. Mean acorn consumption the first week was $2.09 \pm 0.1992 \mathrm{gm}$. dry wt., while that of the second week was $1.48 \pm 0.1425 \mathrm{gm}$. dry wt. Average consumption for the two weeks was $1.79 \pm 0.1288$ gm. dry wt. This was equivalent to one chestnut oak acorn a day. The mice con- 
sumed an average of 10.25 per cent of their body weight daily. All mice lost weight during the trials, with changes for individuals ranging up to 12.54 per cent.

In the second experiment, which involved chestnut oak and white oak acorns, the amount of acorns consumed by individual mice within the two groups did not cliffer significantly, except when the mice in Group A were on the chestnut oak diet. No significant difference in consumption within the groups occurred between days. Mice in Group B, however, differed significantly in their assimilation of both chestnut oak and white oak acorns. They also exhibited significant difference in assimilation between days when they were on the chestnut oak acorn diet. Group A exhibited no difference in assimilation by mice and among days.

The mice consumed a significantly greater quantity and assimilated a higher percentage of chestnut oak than white oak, yet maintained their weight better on a smaller quantity of white oak acorns. No significant difference occurred between trials, and no relationship existed between weight and consumption or between days, assimilation and weight.

The mice consumed a mean of $3.172 \pm 0.1732$ gm. dry wt. daily of chestnut oak acorn and $2.29 \pm 0.0953 \mathrm{gm}$. dry wt. of white oak, significantly different at the 1 per cent level. This is equivalent to 18.41 per cent and 10.89 per cent of body weight daily, respectively. They assimilated 89.45 per cent of the chestnut oak and 85.95 per cent of white oak. Although the mice as a group lost weight on both white oak and chestnut oak, they maintained their weight better on the white oak. Average loss on white oak was 1.86 per cent for a five-day period, while on chestnut oak it was 6.40 per cent.

In the third experiment, the mice showed a decicled preference for white oak over chestnut oak and red oak. Likewise, they destroyed more white oak acorns, including those consumed. Only 19 per cent of chestnut oak acorns breached was eaten. Destruction by individual mice ranged from 68 per cent to 22 per cent of all acorns with which they came in contact.

Based on the facts that acorns alone are not a satisfactory diet for mice, that the mice have a decicled preference for white oak acorns, and that white oak reproduction exceeds that of red oak by 70 per cent, even though red oak is a more abundant seed producer, it is concluded that white-footed mice have little if any influence on oak reproduction. 


\section{Literature Cited}

Abbott, H. G., "White Pine Seed Consumption by Small Mammals." Journ. For., 59:197-201 (1961).

Abbott, H. G. and A. C. Hart, Mice and Voles Prefer Spruce Secd. Northeast Forest Experiment Station Paper No. 153, 12 pp, 1960.

Baumgras, P., "Experimental Feeding of Captive Fox Squirrers." Joum. Wildlife Management, $8: 296-300$ (1944).

Chew, R. M., The Water Exchanges of Some Small Amimals. Unpublished Doctor's Thesis, University of Illinois, 1948.

Christisen, D. M. and L. S. Korschgen, "Acorn Yields and Wildlife Usage in Missouri." Tran. N. A. Wildlife Conference, 337-357 (1955).

Dice, L. R., "Some Factors Affecting the Distribution of the Prairie Vole, Forest Deer Miouse, and Prairie Deer Mouse." Ecol., $3: 29-42$ (1922).

Downs, A. A. and W. C. McQuilken, "Seed Production of Southern Appalachian Oaks." Journ. For., $42: 913-920$ (1944).

Hamilton, W. J., Jr., "Food of Forest Small Mammals in Eastern United States." Journ. Mamm., $22: 250-263$ (1941).

Jameson, E. W., Jr., "Reproduction of Deer Mice (Peromyscus maniculatus and P. boylei) in the Sierra Nevada, California." Journ. Mamm., 34:44-58 (1953).

Jameson, E. W., Jr., "Some Factors Affecting Fluctuations of Microtus and Peromyscus." Journ. Mamm., $36: 206-209$ (1955).

Kincer, J. B. and W. A. Mattice, "Statistical Correlation of Weather Influences on Crop Yields." Monthly Weather Review, 56:53-57 (1928).

Korstian, C. F., Factors Controlling Germination and Early Survival in Oaks. Yale School of Forestry Bulletin 19, 1927.

Krajicek, J. E., Rodents Influence Red Oak Regenaration. Central States Forestry Experiment Station Note No. 91, 1955.

Sealander, J. A., Jr., "Foòd Consumption in Peromyscus in Relation to Air Temperature and Previous Thermal Experience." Journ. Hamm., $33: 206-218$ (1952).

Shaw, W. E., "Direct Seeding in the Pacific Northwest." Journ. For., $52: 827-82 S$ (1954). Snedecor, G., Statistical Methods. Iowa State University Press, 1956.

Smith, C. F. and S. E. Aldous, "The Influence of Mammals and Birds in Retarding Artificial and Natural Reseeding of Coniferous Forests in the United States." Journ. For., $45: 361-367$ (1947).

Spencer, D. A., "Rodents and Direct Seeding." Journ. For., 52 :824-826 (1954)

Tryon, E. H. and K. L. Carvell, Regeneration Under Oak Stands. West Virginia University Agricultural Experiment Station Bulletin 424T, 1958.

Tryon, E. H. and K. L. Carvell, Acorn Production and Damage. West Virginia University Agricultural Experiment Station Bulletin 466T, 1962.

Turcek, F. J., "Quantitative Experiments on the Consumption of Tree-Seeds by Mice of the Species Apodemus flavicollis." Arch. Soc. Zool. Bot. Finnicae. "Vanamo," 10:50-59 (1956).

Verme, L. S. "Acorn Consumption by Chipmunks and White-footed Mice." Journ. Mamm., $38: 129-132$ (1957).

Wainio, W. W. and E. B. Forbes. "The Chemical Composition of Forest Fruits and Nuts From Pennsylvania." Journ. Agr. Research, 62:627-635 (1941).

Willis, C. P., "The Control of Rodents in Field Seeding." Proc. Soc. of Am. Foresters, $9: 365-379(1914)$. 


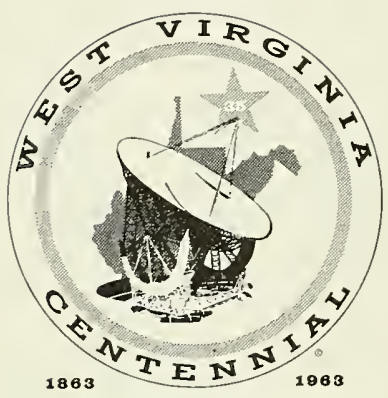

I keeping with the concept and objectives of the West Virginia Centennial, your State University is pleased to participate in the yearlong celebration marking the 100th Anniversary of West Virginia's admission to the Union, and to share in this observance of our heritage and past achievements. 

